\title{
Alfalfa Establishment, Performance, and Persistence in Mississippi When Planted into a Bermudagrass Sward
}

\author{
Joshua A. White, Rocky Lemus \\ Department of Plant and Soil Sciences, Mississippi State University, Starkville, MS, USA \\ Email: jwhite@pss.msstate.edu
}

Received 23 July 2015; accepted 27 August 2015; published 31 August 2015

Copyright (C) 2015 by authors and Scientific Research Publishing Inc.

This work is licensed under the Creative Commons Attribution International License (CC BY). http://creativecommons.org/licenses/by/4.0/

(c) (i) Open Access

\begin{abstract}
Alfalfa is a high quality forage that is not often utilized in the southeastern United States because of its perceived lack of adaptability to the area. However, the risk of growing alfalfa could be partially mitigated by its inclusion into an existing bermudagrass system that makes up a large portion of pastures and hay fields in Mississippi. Alfalfa was planted into an existing bermudagrass hay field at a rate of 17, 22, 28 and $39 \mathrm{~kg} \cdot \mathrm{ha}^{-1}$ in no-till and minimum till sod preparation and analyzed for three growing seasons. Tillage did not affect any of the variables observed but seeding rate and time affected DM (dry matter) yield, forage nutritive value and plot composition. The increasing alfalfa seeding rate increased alfalfa yield in the plot but this was isolated to only the first year. Dry matter yields decreased over the three years due to the decrease in alfalfa composition, but throughout the growing season DM yields increased after the first year suggesting bermudagrass recolonization within the plot. Forage nutritive value was positively affected with as little as $20 \%$ of the plot composed of alfalfa suggesting that even thinning stands by the third year might offer economic advantages.
\end{abstract}

\section{Keywords}

Alfalfa, Bermudagrass, Alfalfa Bermudagrass Mixtures, Grass Legume Mixtures

\section{Introduction}

Warm-season perennial sod grasses such as bermudagrass (Cynodondactylon L.) make up the majority of pasture systems in the southeastern United States. Mississippi is comprised of nearly 800,000 acres of bermudagrass which is used as pasture and hay [1]. In general, bermudagrass tends to be poor to moderate nutritive value 
when nitrogen input remains minimal [2]. In the midst of rising nitrogen prices [3], hay producers in Mississippi are forced to examine other alternatives to retain the quality of their hay without complete reliance on nitrogen fertilizer. One method of improving the nutritive quality of warm-season perennials involves overseeding coolseason legumes. Legumes have the potential to increase overall nitrogen to the system as well as increase yearly dry matter yields [4]. Annual and perennial clovers such as white clover (Trifolium repens) and crimson clover (Trifolium incarnatum) are commonly grown in mixed pastures in Mississippi. However, they are relatively unproductive outside the early spring months; therefore, they cannot be relied on to improve warm-season grass pastures during peak growth periods of the grass.

In contrast to other cool-season legumes, alfalfa (Medicago sativa L.) is productive through the summer with the possible exception of July and August [5]. As a result of cultivar improvement, alfalfa has shown potential in Mississippi and other southeastern states, as a forage crop. Alfalfa stands in Mississippi have produced annual yields comparable to that of the lower range $\left(6000 \mathrm{~kg} \cdot \mathrm{ha}^{-1}\right)$ of the southwestern United States [5] [6]. However, stands still tend to thin after the $2^{\text {nd }}$ year or succumb to disease pressure, suggesting the need to minimize risk by overseeding into existing pastures. Overseeding alfalfa into bermudagrass can improve hay quality while increasing annual dry matter yields in the spring and fall months while bermudagrass is unproductive. Using perennial grass sods as a companion crop with alfalfa could also provide a sink source for residual nitrogen from decomposing alfalfa plants and act as supplemental biomass in thinning alfalfa stands.

A study conducted in East Texas with alfalfa/bermudagrass indicated that very little fixed $\mathrm{N}$ was passed onto the grass [7]. The authors attributed these results to the poor survival and growth rate of the bermudagrass in the stand. Evidence suggests that it is not only important to consider the nitrogen production potential of the legume, but also the ability for the associated grass to utilize residual nitrogen by successfully competing in a mixed stand. It has been demonstrated, more than once, that a decline in bermudagrass stands is common when overseeded with alfalfa [7] [8]. This decline in bermudagrass is primarily associated with the aggressive upright growth of alfalfa a subsequently shading out bermudagrass.

The main objective of this research was to evaluate the performance of alfalfa bermudagrass mixtures when alfalfa is overseeded into existing bermudagrass. The effect of alfalfa seeding rate and sod preparation on the establishment and persistence of both the bermudagrass and alfalfa was observed over three years.

\section{Materials and Methods}

The study was planted in a Kipling silty clay loam (fine, smectitic, thermic Vertic Paleudalfs) soil type located at the Henry H. Leveck Animal Research Center $\left(33^{\circ} 25^{\prime} 53.07^{\prime \prime} N\right.$, $\left.88^{\circ} 47^{\prime} 11.15^{\prime \prime W}\right)$. A Round-up Ready ${ }^{\circledR}$ alfalfa cultivar; DKA41-18RR (Monsanto, St Louis, MO.) was planted at a rate of 17, 22, 28 and $39 \mathrm{~kg} \cdot \mathrm{ha}^{-1}$ into an existing mixed bermudagrass hay field on October 27, 2011. Round-up ready alfalfa cultivars allow for the use of glyphosate as a non-specific chemical weed control over the alfalfa. The residual bermudagrass was cut to 7.62 $\mathrm{cm}$ and the biomass removed before planting. The experimental design is a split plot design replicated four times. The main plots were tillage types and subplots were alfalfa seeding rates. Two types of tillage methods was used to prepare the sod for alfalfa planting described as minimum tillage and no-tillage which received no sod preparation. While many standards can be used to define tillage intensity, minimum tillage was characterized in this study as the process of tilling with a $1.5 \mathrm{~m}$ disc to only a $2.54 \mathrm{~cm}$ depth to disturb the sod. The resulting sod was broke but still intact to and level to potentially provide greater seed to soil contact. Subplots were $1.8 \mathrm{~m}$ wide $\times$ $4.5 \mathrm{~m}$ long and planting was accomplished using a no-till Almaco plot cone planter (Almaco, Nevada, IA). No nitrogen was applied to the plots at any time during the trial. Trial area was amended with lime and $\mathrm{K}_{2} \mathrm{O}$ at planting according to the Mississippi State University soil testing recommendations. As a result the one ton of lime and $67 \mathrm{~kg} \cdot \mathrm{ha}^{-1}$ of $\mathrm{K}_{2} \mathrm{O}$ were added to satisfy recommendations. At midseason another $67 \mathrm{~kg} \cdot \mathrm{ha}^{-1}$ of $\mathrm{K}_{2} \mathrm{O}$ was added each year. Before each harvest visual observations were taken of each plot to estimate alfalfa species composition present in the harvest.

Plots were harvested when alfalfa reached a $10 \%$ bloom or later depending on the time of year from 2012 to 2014. Harvesting was accomplished using a commercial Ferris Z-turn mower (Munnsville, NY) equipped with a bagging system. The harvest schedule is represented in Table 1. Each sub plot was then weighed to determine forage yields and subsamples collected for dry matter determination. The sub-sample was taken and dried in a force air oven at $55^{\circ} \mathrm{C}$ until the weight remained constant. The sample was ground to pass through a 2-mm screen using a Wiley mill (Thomas Scientific, Swedesboro, NJ) and analyzed for Neutral Detergent Fiber (NDF), 
Table 1. Harvest dates from 2012-2014 in Starkville, MS.

\begin{tabular}{cccc}
\hline & Harvest Dates & & \\
\hline 2012 & 2013 & 2014 \\
\hline April 19 & May 8 & May 13 \\
May 24 & June 10 & June 12 \\
July 17 & July 3 & July 14 \\
August 23 & August 27 & August 22 \\
\hline
\end{tabular}

Acid Detergent Fiber (ADF), and Crude Protein (CP) using a Foss 6500-C Near Infra-red Reflectance Spectroscopy (NIRS) instrument (Foss North America, Eden Prairie, MN) using the legume and grass hay equations developed by the NIRS Forage and Feed Testing Consortium (Hillsboro, WI).

Data was analyzed using year as a repeated measure for each dependent variable (Table 2 and Table 3). Data was further analyzed in the PROC GLM in SAS and the least significant difference was used to determine differences between treatments at $\alpha=0.05$ (SAS, 2013). Correlations were analyzed using PROC CORR in SAS (SAS, 2013) for the following comparisons: alfalfa composition vs. year and DM yield and year vs DM yield. Regression analysis was performed using PROC REG in SAS and alfalfa composition was regressed with DM yield, ADF, NDF and CP.

\section{Results}

\subsection{Statistical Results}

Tillage had no effect on total yield, harvest yield, alfalfa composition or forage nutritive value in any circumstance across the span of the study. Using year as a repeated measure for total annual forage DM (dry matter) yield had no significant effects.

\subsection{Total Annual DM Yield}

Year effect was a main factor $(P=0.0001)$ on total forage yield with a steady decrease in biomass production from 2012 to 2014 (Table 2). In 2012 total annual yields were over $6700 \mathrm{~kg} \cdot \mathrm{ha}^{-1}$ with a $30 \%$ decrease in DM production every subsequent year. A correlation analysis found forage DM yield to be negatively correlated with year $(P=0.001)$.

\subsection{Harvest DM Yield}

Dry matter yields were influenced by main effects; harvest date and alfalfa seeding rate (Figure 1). These variables further interacted with year when year effect was analyzed. Alfalfa seeding rate only effected DM yield in $2012(P=0.02820)$ in plots planted at $22 \mathrm{~kg} \cdot \mathrm{ha}^{-1}$ which produced less yield than the other seeding rates. Regardless of alfalfa seeding rate, harvest DM yields increased in 2012 from April to August due to higher alfalfa composition in the harvest. In the subsequent years, 2013 and 2014, DM yields were relatively higher in the last harvest. The shift in DM yields with harvest timing suggests an increased in bermudagrass recolonization into thinning alfalfa plots.

\subsection{Alfalfa Composition}

Harvest date had a significant effect on alfalfa composition, when analyzed without year influence $(P=0.0001)$. However, year interaction with harvest and seeding rate were significant $(P=0.001)$. In general, alfalfa composition during the establishment year increased with increasing seeding rate. However, this effect was mitigated by the Year 2 and Year 3 of the study. In the establishment year (2012), alfalfa composition was 100\% by the first harvest and decreased by $50 \%$ by the second harvest and made up 38\% of the plot in the third and fourth harvests. In the second year (2013), alfalfa again made up nearly $100 \%$ of the first harvest and decreased almost $50 \%$ by the second, third and fourth harvests. In the third year (2014), the first harvest was made up of less than $70 \%$ alfalfa and decreased to under $50 \%$ by the third harvest and again decreased to $20 \%$ of the harvest by the 
Table 2. Analysis of variance for total annual DM forage yield.

\begin{tabular}{ccc}
\hline Source & DF & $P$ values \\
\hline Year (A) & 2 & 0.0001 \\
Tillage (B) & 1 & 0.4154 \\
Rate (C) & 3 & 0.3394 \\
A $\times$ B & 2 & 0.6698 \\
A $\times$ C & 6 & 0.2918 \\
B $\times$ C & 3 & 0.4382 \\
A $\times$ B $\times$ C & 6 & 0.2051 \\
\hline
\end{tabular}

Table 3. Analysis of variance forage DM yield, Alfalfa composition, ADF, NDF, and CP.

\begin{tabular}{ccccccc}
\hline Source & DF & DM yield & Alfalfa Composition & ADF & NDF & CP \\
\hline Year (A) & 2 & 0.0001 & 0.0002 & 0.0001 & 0.0001 & 0.0001 \\
Harvest (B) & 3 & 0.0001 & 0.0001 & 0.0001 & 0.0001 & 0.0001 \\
Tillage (C) & 1 & 0.1910 & 0.4096 & 0.5523 & 0.4289 & 0.9010 \\
Rate (D) & 3 & 0.0051 & 0.3991 & 0.8432 & 0.9383 & 0.8913 \\
A $\times$ B & 6 & 0.0001 & 0.0001 & 0.0001 & 0.0001 & 0.0001 \\
A $\times$ C & 2 & 0.5768 & 0.0621 & 0.9214 & 0.5831 & 0.1928 \\
A $\times$ D & 6 & 0.0380 & 0.0001 & 0.8065 & 0.7149 & 0.0562 \\
B $\times$ C & 3 & 0.7521 & 0.9807 & 0.8585 & 0.8081 & 0.9133 \\
B $\times$ D & 9 & 0.9780 & 0.9628 & 0.9232 & 0.9816 & 0.9022 \\
C $\times$ D & 3 & 0.1759 & 0.0652 & 0.0752 & 0.0832 & 0.0633 \\
A $\times$ B $\times$ C & 6 & 0.0752 & 0.3689 & 0.9432 & 0.9264 & 0.8889 \\
A $\times$ B $\times$ D & 18 & 0.1992 & 0.2387 & 0.6169 & 0.8622 & 0.9397 \\
B $\times$ C $\times$ D & 9 & 0.9999 & 0.8887 & 0.9270 & 0.9212 & 0.9508 \\
\hline
\end{tabular}

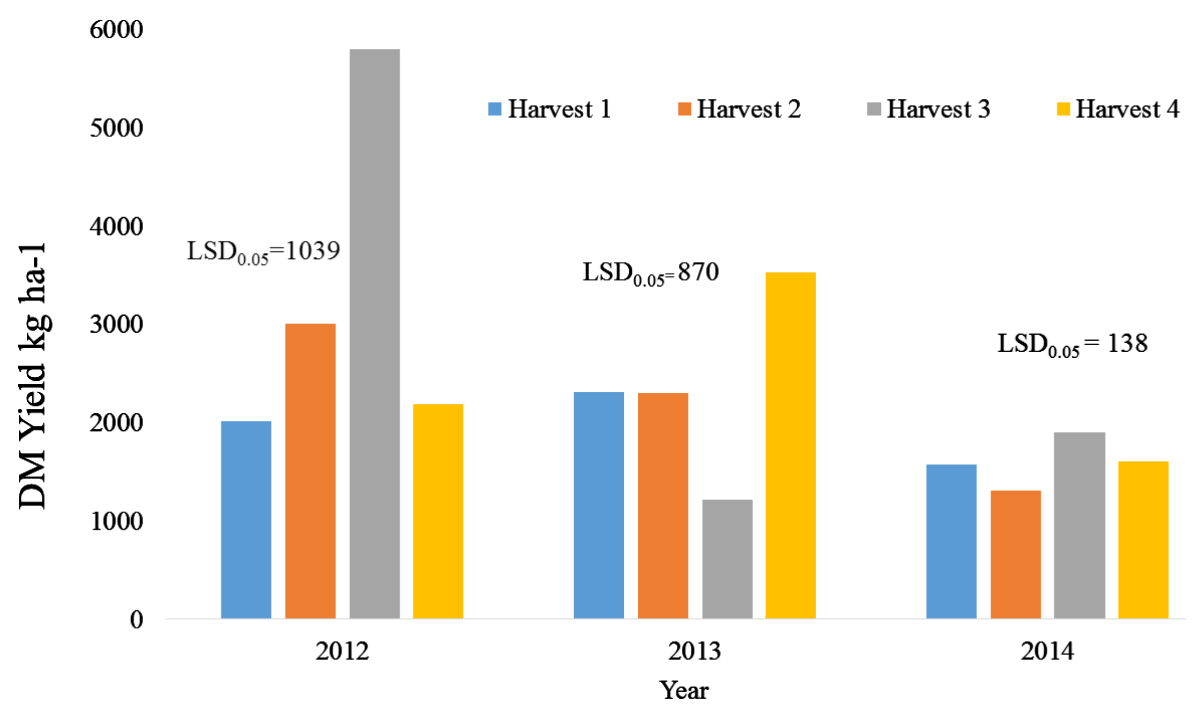

Figure 1. Dry matter yields from 2012-2014, separated by harvest and considered significant at $P=0.05$ using Fishers LSD. 
last harvest. Alfalfa composition was negatively correlated with year $(P=0.0015)$ and DM yield $(P=0.001)$.

\subsection{Forage Nutritive Value}

Forage nutritive value measured as ADF, NDF and CP and analyzed without year influence was only affected by harvest date. When year was considered, an interaction with harvest date was significant for each variable. In the establishment year both ADF and NDF increased with each successive harvest and CP decreased by the third and fourth harvests. In the second year, ADF and NDF again increased with each harvest, but CP remained the same until the last harvest where it decreased from $20 \%$ to $11 \%$. By the third year, ADF fractions increased by the third and fourth harvests, but NDF fractions increased with each harvest. Crude protein was the greatest in the first and second harvest, but decreased to less than $15 \%$ in the third and fourth harvest. A regressions analyses describing percent alfalfa in the plot in relation to ADF, NDF, and CP were all found to be significant $(P=$ 0.001) (Figure 2).
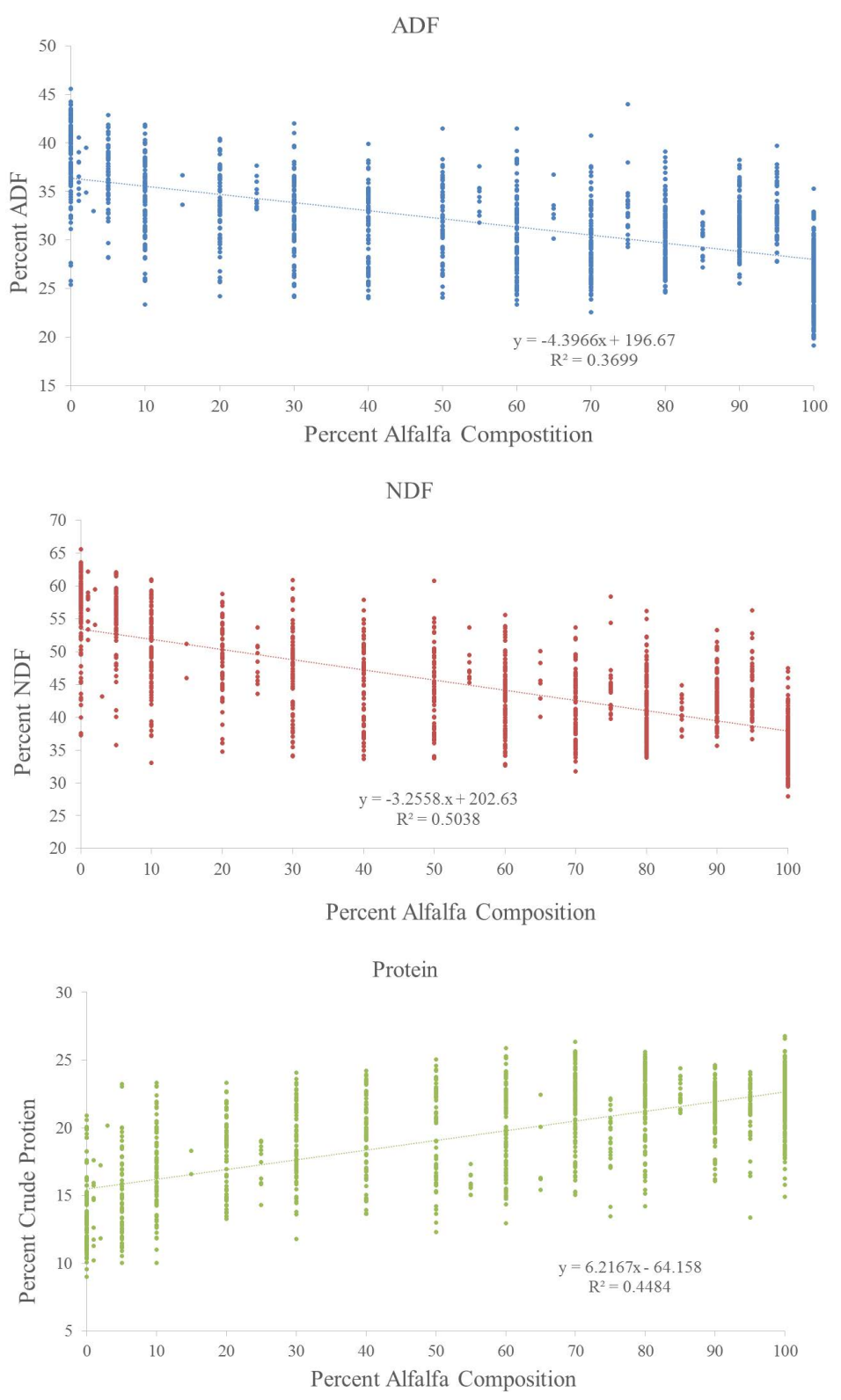

Figure 2. Linear regressions of percent alfalfa composition with ADF, NDF, and CP. 


\section{Discussion}

The use of minimum tillage to aid in establishing alfalfa stands did not influence alfalfa establishment into sod grasses. In fact, the use of minimum tillage may have encouraged annual weedy grass encroachment growth like crabgrass (Digitaria sanguinalis) and yellow foxtail (Setaria pumila). The success of alfalfa in this no-till application relative to minimum tillage may also be a product of fall planting when bermudagrass is dormant limiting competition and adequate soil moisture for the seedling survival exist.

Seeding rate in many crops is often used to control the resulting plant population in many applications. In some instances, seeding rates are usually increased when legumes are planted into a sod to encourage adequate stand establishment. However, this advantage was not evident when using DM yields as an indicator. Though DM yield did not indicate differences among alfalfa seeding rates, greater forage yields were correlated with increasing alfalfa composition in the plot. Furthermore, visual estimations of alfalfa composition within the plot did generally increase with increasing seeding rate, but this was only isolated to the first year. This effect is similar to those found by Hall et al. [9] where seeding rates of alfalfa over $17 \mathrm{~kg} \cdot \mathrm{ha}^{-1}$ did not improve stand persistence in a 4-year trial. After the first year, alfalfa composition was mainly effected by harvest date regardless of seeding rate. Considering the current cost of conventional alfalfa seed to be more than $\$ 6.00 / \mathrm{kg}$ and Round-up Ready ${ }^{\circledR}$ seed to be more than $\$ 12.00 / \mathrm{kg}$; greater seeding rates did not offer an economic advantage.

Alfalfa composition had slowly declined by the third year along with DM yields and forage nutritive value. The proceeding discussion uses forage nutritive standards established by the American Forage and Grassland Council labeled as Prime, 1, 2, 3, 4, and 5 for grass and legume hay [10]. These standards use ADF, NDF, and $\mathrm{CP}$ as constituents to rate hay quality with "Prime" representing the best quality and " 5 " being the worse quality. Forage quality was considered Prime the first and second harvest of the first and second year and decreased no lower than a " 3 " by the last harvest of first year. By the last harvest of 2013, fiber values decreased forage quality to a "4," but maintained good CP values. This was likely due to alfalfa harvested at late maturity rather than increased bermudagrass composition since very little bermudagrass had re-established itself by the second year. By 2014, the forage quality was never rated Prime, but was consistently rated between 1 - 3 largely due to greater NDF and lower CP values. This trend was most likely due to decreasing alfalfa composition and increasing grass composition. Fiber quality was maintained while $\mathrm{CP}$ values decreased due to the increase in immature grass being harvested in the plot. This effect was amplified because due to the parameters of the study where no nitrogen was applied which resulted in very little grass growth. The effect is most evident in 2014 where alfalfa composition made up less than $20 \%$ of the forage harvested. Yield must also be taken into account considering total yields of less than $6000 \mathrm{~kg} \cdot \mathrm{ha}^{-1}$ which are less than bermudagrass and most alfalfa forage yields in pure plots.

The use of nitrogen application to encourage grass growth in legume grass mixtures has negative effects on the nitrogen fixed by the accompanied legume. A decrease in nitrogen fixed by the Rhizobium can be expected with minimal rates of applied nitrogen. McAuliffe et al. [11] found that the percent of fixed nitrogen in 10-week old alfalfa plants decreased from $58 \%$ to $17 \%$ with the addition of $22-89 \mathrm{~kg} \mathrm{~N} \mathrm{ha}^{-1}$. However, most producers do not have the ability or not find it economically sound to fertilize with nitrogen rates less than $56 \mathrm{~kg} \cdot \mathrm{ha}^{-1}$. The main reason for alfalfa inclusion into bermudagrass is its ability to fix nitrogen from the air. It is only logical to decide a threshold for the mixture composition and forage yield to which economical nitrogen rates can again be applied for grass production. This may be simply done using the potential yield and forage value of bermudagrass receiving $112 \mathrm{~kg} \mathrm{~N} \mathrm{ha}^{-1}$ compared to the alfalfa bermudagrass mixture receiving $0 \mathrm{~kg} \mathrm{~N} \mathrm{ha}^{-1}$. The relatively predictable linear regressions equation for yield and forage quality compared to alfalfa composition was utilized to develop an economic threshold. In well managed improved bermudagrass pastures in Mississippi receiving $112 \mathrm{~kg} \mathrm{~N} \mathrm{ha}^{-1}$ in split applications, DM yield, ADF, NDF, and CP were $1699 \mathrm{~kg} \cdot \mathrm{ha}^{-1}, 36 \%, 64 \%$, and $10 \%$ respectively [12]. Using these paremeters and the predictive equations from Figure 1, DM yield would be matched when alfalfa composed only $60 \%$ of the mixture. In addition, mixtures containing less than $20 \%$ alfalfa could still produce lower NDF values and greater CP values than well managed bermudagrass. Bermudagrass alone will have similar ADF values grass/legume mixed systems with less than $40 \%$ alfalfa. Considering that forage nutritive value must be compromised with forage yield, the data suggest that after the second harvest of the third year alfalfa composition, yield and forage nutritive value have all decreased enough to justify a shift in management for ideal bermudagrass management.

The parameters of this trial considered management and responses according to alfalfa alone. However, sev- 
eral trials have concluded that a more balanced competition between bermudagrass and alfalfa could be maintained when wider alfalfa row spacing and timely nitrogen application were utilized. Haby et al. [8] demonstrated successfully that alfalfa at wider row $(69-\mathrm{cm})$ spacing increased bermudagrass yields by nearly $56 \%$ when compared to 23-cm row spacing. However, alfalfa yields decreased when row spacing increased, resulting in lower crude protein (CP) concentrations even though total forage yield was not affected. The same study also observed the effect of $\mathrm{N}$ application and found that bermudagrass yield increased with increasing nitrogen input, but only the first two years [8]. This data, however, in contrast to a review by Brown and Byrd [13] indicated that no changes in species composition or total yield with nitrogen inputs up to $100 \mathrm{~kg} \cdot \mathrm{ha}^{-1}$ and row spacing of 15 to $30-\mathrm{cm}$.

\section{Conclusion}

It was evident in the current study that bermudagrass was negatively impacted by alfalfa especially in the first year. Even though alfalfa decreased in composition of the plot with each harvest year, the remainder of the plot was not necessarily composed of bermudagrass. Instead, annual weedy grasses that took advantage of bermudagrass died off. In most plots by the third year, bermudagrass had begun to advance back due in part to the un-manipulated space between treatment strips. If alfalfa was entirely overseeded in a bermudagrass pasture, intense and possibly unrecoverable suppression of the bermudagrass could be expected.

\section{Acknowledgements}

Approved for publication as Journal Article No. J-12706 of the Mississippi Agricultural and Forestry Experiment Station, Mississippi State University.

\section{References}

[1] Lemus, R. (2008) Mississippi Forage Survey. Unpublished, Mississippi Coop Ext. Serv., Mississippi State, MS.

[2] Johnson, C.R., Reiling, B.A., Mislevy, P. and Hall, M.B. (2001) Effects of Nitrogen Fertilization and Harvest Date on Yield, Digestibility, Fiber, and Protein Fractions of Tropical Grasses. Journal of Animal Science, 79, 2439-2448.

[3] United States Department of Agriculture: Economic Research Service (2013) Average U.S. Farm Prices of Selected Fertilizers, 1960-2012. http://www.ers.usda.gov/data-products/fertilizer-use-and-price.aspx\#26727

[4] Ledgard, S.F. and Steele, K.W. (1992) Biological Nitrogen Fixation in Mixed Legume/Grass Pastures. Plant and Soil, 141, 137-153. http://dx.doi.org/10.1007/BF00011314

[5] White J., Lemus, R., Saunders, J.R. and Fitzgerald, L. (2012) Mississippi Perennial Cool-Season Forage Crop Cultivar Trials, 2012. Mississippi Agriculture and Forestry Experiment Station Bull. 476.

[6] Putnam, D.H., Orloff, S.B. and Teuber, L.R. (2007) Irrigated Alfalfa Management: Choosing an Alfalfa Cultivar. Ch. 5. ANR Pub., Oakland, 8291.

[7] Haby, V.A., Stout, S.A., Hons, F.M. and Lenoard, A.T. (2006) Nitrogen Fixation and Transfer in a Mixed Stand of Alfalfa and Bermudagrass. Agronomy Journal, 98, 890-898. http://dx.doi.org/10.2134/agronj2005.0084

[8] Haby, V.A, Rouquette Jr., F.M., Leonard, A.T. and Hons, F.M. (1999) Alfalfa Production on Acid, Humid-Regions Soils. American Forage and Grassland Council Proceedings 6, Fort Worth, 13-15.

[9] Hall, M.H., Nelson, C.J., Coutts, J.H. and Stout, R.C. (2004) Effect of Seeding Rate on Alfalfa Stand Longevity. Agronomy Journal, 96, 717-722. http://dx.doi.org/10.2134/agronj2004.0717

[10] Marshalls, M.A., Hagevoort, G.R., Lauriault, L.M. (2014) Hay Quality, Sampling, and Testing. New Mexico State University, Las Cruces, Circular 641.

[11] McAuliffe, C., Chamblee, D.S., Uribe-Arango, H. and Woodhouse Jr., W.W. (1957) Influence of Inorganic Nitrogen on Nitrogen Fixation by Legumes as Revealed by $\mathrm{N}^{151}$. Agronomy Journal, 50, 24.

[12] Lemus, R. and White, J. A. (2013) Bermudagrass Nitrogen and Harvest Timing. Unpublished Data.

[13] Brown, R.H. and Byrd, G.T. (1990) Yield and Botanical Composition of Alfalfla-Bermudagrass Mixtures. Agronomy Journal, 82, 1074-1079. http://dx.doi.org/10.2134/agronj1990.00021962008200060009x 